\title{
Aqueous enzymatic extraction of palm kernel oil
}

\section{Firman Sebayang}

Department of Chemistry, Faculty of Mathematics and Natural Sciences, Universitas Sumatera Utara, Medan 20155, Indonesia. Carbon Research Centre, Universitas Sumatera Utara, Medan 20155, Indonesia Juliati Br. Tarigan

Department of Chemistry, Faculty of Mathematics and Natural Sciences, Universitas Sumatera Utara, Medan 20155, Indonesia. Carbon Research Centre, Universitas Sumatera Utara, Medan 20155, Indonesia Mahlil Rizki

Department of Chemistry, Faculty of Mathematics and Natural Sciences, Universitas Sumatera Utara, Medan 20155, Indonesia

\section{Ferizha Cinthya Utami}

Department of Chemistry, Faculty of Mathematics and Natural Sciences, Universitas Sumatera Utara, Medan 20155, Indonesia

\section{Taslia Anggriwati Hutagalung}

Department of Chemistry, Faculty of Mathematics and Natural Sciences, Universitas Sumatera Utara, Medan 20155, Indonesia

\section{Misdwati Misdawati}

Department of Civil Engineering, Universitas Al Washliyah, Medan 20147, Indonesia.

\section{Justaman A. Karo-karo}

Balai Riset dan Standarisasi Industri, Kementerian Perindustrian, Medan 20214, Indonesia

\section{Suvimol Charoensiddhi}

Department of food science and technology, Faculty of Agro-Industry, Kasetsart University, Bangkok, Thailand 10900

\section{Eko Kornelius Sitepu ( $\nabla$ ekositepu@usu.ac.id )}

Universitas Sumatera Utara https://orcid.org/0000-0003-3565-9027

\section{Research}

Keywords: digestive drug, palm kernel, lipid profile, green metric

Posted Date: December 9th, 2020

DOl: https://doi.org/10.21203/rs.3.rs-121866/v1

License: (c) (i) This work is licensed under a Creative Commons Attribution 4.0 International License. 



\section{Aqueous enzymatic extraction of palm kernel oil}

2

3 Firman Sebayang, ${ }^{\text {a,b }}$ Juliati Br. Tarigan, ${ }^{\text {a,b }}$ Mahlil Rizki, ${ }^{a}$ Ferizha Cinthya Utami, ${ }^{a}$

4 Taslia Anggriwati Hutagalung, ${ }^{a}$ Misdawati, ${ }^{c}$ Justaman A. Karo-karo, ${ }^{d}$ Suvimol

5 Charoensiddhi, ${ }^{\mathrm{e}}$ and Eko K. Sitepu ${ }^{\mathrm{a}, \mathrm{b} *}$

6

7 a Department of Chemistry, Faculty of Mathematics and Natural Sciences,

8 Universitas Sumatera Utara, Medan 20155, Indonesia.

9 b Carbon Research Centre, Universitas Sumatera Utara, Medan 20155, Indonesia

10 c Department of Civil Engineering, Universitas Al Washliyah, Medan 20147, 11 Indonesia.

12 d Balai Riset dan Standarisasi Industri, Kementerian Perindustrian, Medan 20214, 13 Indonesia.

14 e Department of food science and technology, Faculty of Agro-Industry, Kasetsart 15 University, Bangkok, Thailand 10900.

16

17 *Corresponding author: ekositepu@usu.ac.id 
19 Abstract

20

21 Inexpensive enzyme with high hydrolitic activity is required to bring the aqueous 22 enzymatic extraction (AEE) of seed / biomass oil into commercialization. In this study 23 a commercial digestive drug which is mainly composed of amylase and protease 24 enzymes has been applied to extract the palm kernel oil. A single factor experiment 25 evaluated the effect of the ratio palm kernel to water, concentration of digestive drug 26 used, $\mathrm{pH}$, incubation time and temperature on extraction efficiency, free fatty acid 27 (FFA) content and lipid profile in form of monoglyceride, diglyceride and triglyceride. 28 A significant effect was observed for all the parameters and the highest extraction 29 efficiency of $96 \%$ with FFA content less than $0.68 \%$ was observed in the incubation 30 condition of $1: 5$ ratio palm kernel to water, $9 \% \mathrm{w} / \mathrm{w}$ of digestive drug, $\mathrm{pH}$ of $9,90 \mathrm{~min}$ 31 of incubation time at $45^{\circ} \mathrm{C}$. Green metrics assesment confirmed that the AEE process is more green process than the soxhlet method. In comparison with other existing extraction methods, the AEE showed better extraction efficiency against the screw press and supercritical carbon dioxide methods.

36 Keywords: digestive drug, palm kernel, lipid profile, green metric. 


\section{Introduction}

39

40

41

42

43

44

45

46

47

48

49

50

51

52

53

54

55

56

57

58

59

60

61

62

63

64

65

66

67

68

69

The world vegetable oil consumption has increased 2.3\% per annum during the past two decades of $21^{\text {st }}$ century, with China and Brazil as the highest consumers at 30 and $24 \mathrm{~kg} /$ capita. Consumption is predicted to continue to rise by $0.9 \%$ in the coming years (OECD et al. 2020). Currently mechanical pressing and solvent based extraction methods were used in the oil industry (Cheng and Rosentrater 2017). Hexane is the most popular extraction solvent due to its high extraction yield and low cost (Cheng and Rosentrater 2017). However, hexane is toxic, flammable and classified as a pollutant (Potrich et al. 2020; Toda et al. 2016). Therefore, greener extraction processes have been developed recently using green solvents such as carbon dioxide, ethanol, ethyl acetate, etc (He et al. 2020; Dal Prá et al. 2018; Castejón et al. 2018; Castro-Puyana et al. 2017; Toda et al. 2016). The carbon dioxide extraction process is usually conducted in a supercritical condition to produce a good yield and pure oil (Costa et al. 2019; Mouahid et al. 2018). Even though the polar solvents could not dissolve oil, some researchers have confirmed the oil could be extracted with a comparable yield using a polar solvent (de Oliveira et al. 2013; de Jesus et al. 2019; Kumar et al. 2017). For example, Castejòn et al found that ethanol could extract more oil from Echium plantagineum $L$ seeds than hexane assisted by ultrasound particularly at $55^{\circ} \mathrm{C}$ (Castejón et al. 2018). However, those green processes required a high temperature and pressure in a prolonged reaction time and consume a lot of solvent (de Jesus et al. 2019; Sitepu et al. 2020).

Another green extraction process was using enzyme in aqueous environment. The extraction efficiency of AEE on some oilseeds materials such as soybean, peanut, sesame, and Moringa oleifera, as well as shrimp by-product has been reported as higher (Liu et al. 2020; Wenwei et al. 2019; Mat Yusoff et al. 2016; Mat Yusoff et al. 2015; Latif and Anwar 2011). Enzymes could hydrolize the cell wall of oil bearing materials releasing oil to the system (Liu et al. 2020; Mat Yusoff et al. 2016; Mat Yusoff et al. 2015; Li et al. 2011; Latif and Anwar 2011). The use of enzyme in an AEE process has some advantages including being environmentally friendly, inexpensive because of the use of water as 
solvent, easy to separate, and finally, having better appearance and taste of the oil product (Mat Yusoff et al. 2015). Moreover, valuable materials contained in the residue such as protein and carbohydrate could be used for other food purposes (Wenwei et al. 2019). Latif and Anwar concluded that the protein which is also extracted in the AEE process has better quality and could be used for human consumption (Latif and Anwar 2011). In addition the degumming oil process which is energy intensive (Yao et al. 2020) has been simultaneously processed in AEE as water dissolves the phospholipid (Zhao et al. 2020; Teixeira et al. 2013).

80

The compounds composed in the cell walls affect the choice of enzyme type and or its combination (Mat Yusoff et al. 2015). The extracted soybean oil was observed to increase when using Alcalase, endo-protease enzyme, while the extracted oil was decreased when using cellulase enzyme (Jung and Mahfuz 2009; Lamsal et al. 2006). Indeed the rapeseed cell walls were easier to break by pectinase than other types of enzymes, which proved that the main component of their cell walls is pectin (Zhang et al. 2007). Some oilseed cell walls required a mixture of enzyme to disrupt. For example sunflower oil increased significantly when using Viscozyme to rupture the cell walls (Latif and Anwar 2009) and a similar effect was also observed on the AEE of bush mango kernel flour (Womeni et al. 2008). Long et al obtained a high oil yield of flaxseed when using a combination of cellulase, pectinase and hemicellulase in same ratio as the enzyme itself (Long et al. 2011). However, enzyme is expensive and requires a significant amount to hydrolyze the cell walls for oil extraction. Yusoff et al reported that more than 1\% of enzyme based on the weight of oil extracted, was needed to proceed the hydrolysis reaction, which therefore raising the production cost (Mat Yusoff et al. 2015).

An immobilization enzyme for the AEE process has been developed to overcome the cost issue. The main advantage of using an immobilized enzyme is the possibility of using it several times without losing its activity (Wan et al. 2008; Santos et al. 2020). Long et al have successfully immobilized a mixture of cellulase, pectinase and hemicellulase onto alginateglutaraldehyde matrix to hydrolyze cell walls of flaxseed. Results showed that 
105 the enzyme could be reused and lowering the production cost (Long et al. 106 2011). However, the result of enzyme reusability has not been cleared yet. 107 Other researchers observed that papain enzyme could be used several times 108 in the AEE of Sacha inchi seed oil with only a slight decrease in the oil yield. It 109 was suggested to add more enzymes to hold the hydrolytic activity same as 110 the first stage (Nguyen et al. 2020). Therefore, finding a low cost enzyme is 111 necessary to enable implementation of the AEE process on an industrial scale.

113 The pancreatin drug which contained a mixture of enzyme lipase, amylase and 114 protease has been used worldwide to repair human digestion (Lebenthal et al. 1994). 115 Many manufacturers have produced the pancreatin drug with different brand names 116 and doses of enzymes (Drugbank 2005). This drug opens the possibility of use in the 117 AEE process. To the best of our knowledge, no literatures have been reported the 118 utilization of a digestive drug as an enzyme source for the AEE process. Therefore, 119 this present study aimed to extract palm kernel oil using a mixture of the enzymes contained in pancreatin drug in an aqueous system. The single effect of the palm kernel : water ratio, $\mathrm{pH}$, temperature, incubation time, and the concentration of digestive drug used was studied in order to achieve the optimized condition. The yields of extracted oil, FFA content, and lipid composition (monoglyceride (MG), diglyceride (DG) and triglyceride (TG)) were determined. Also, the reusability of the enzymes was measured. Finally the green chemistry metrics were calculated to determine how green the AEE process is.

\section{Materials and methods}

\subsection{Materials}

The palm kernel was collected from a local palm oil processing plant in Medan, Sumatera Utara - Indonesia. All chemicals were purchased from a local chemicals distributor and were used without pre-treatment. The digestive drug (brand name Vitazym) used in this study contains Amylase 10,000 IU, protease 9,000 IU, lipase $240 \mathrm{IU}$, DHA $30 \mathrm{mg}$, simeticone $25 \mathrm{mg}$, vit $\mathrm{B}_{1} 10 \mathrm{mg}$, vit $\mathrm{B}_{2} 5 \mathrm{mg}$, vit $\mathrm{B}_{6} 5 \mathrm{mg}$, vit $\mathrm{B}_{12}$ $5 \mathrm{mcg}$, niacinamide $10 \mathrm{mg}$, Ca pantothenate $5 \mathrm{mg}$ (MIMS 2020) and was bought from local pharmacies. 
140 The traditional extraction soxhlet method was used to determine the quantity of palm 141 kernel oil and the result was compared with the AEE. The procedure we followed for 142 the soxhlet extraction has been reported elsewhere (Al-Hamamre et al. 2012; 143 Tarigan et al. 2019). About $20 \mathrm{~g}$ of grounded palm kernel was extracted in the 144 soxhlet apparatus using hexane as an extracting agent under reflux condition for 30 145 minutes. The oil was collected and weighed after solvent evaporation and stored in a 146 desiccator for gas chromatography (GC) analysis.

\subsection{Aqueous enzyme extraction of palm kernel}

149 The ground palm kernel seeds were mixed with water at investigated ratio ranging from 1:3-1:7 (w/v) and the digestive drugs was added according to explored concentration $(\%, w / w)$. Next, the $\mathrm{pH}$ was adjusted with $\mathrm{NaOH}$ or $\mathrm{HCl}$ following investigated value and incubated in the shaking incubator (Vision model VS8480SN) at an appropriate temperature and time. The oils were separated from water and residue using centrifuge running at $8000 \mathrm{rpm}$ for 5 minutes and was stored in a desiccator for analysis. The acid value was determined by the standard titration method following ASTM D664. The AEE oil yield was calculated following equation 1. The extraction efficiency was measured based on the comparison between AEE and soxhlet oil yield.

$$
\text { Yield }_{A E E}=\frac{W_{A E E}}{W_{\text {palm kernel }}}
$$

$$
\text { Extraction Efficiency }(\%)=\frac{\text { Yield }_{A E E}}{\text { Yield }_{\text {Soxhlet }}} \times 100 \%
$$

where $W_{A E E}$ is the weight of AEE oil extracted and $W_{\text {palm kernel }}$ is the weight of palm 162 kernel used.

\subsection{Lipid content and fatty acid profile analysis}

165 The lipid profile i.e. monoglyceride, diglyceride and triglyceride containing in each palm kernel oil extracted was determined using gas chromatography. A $1 \mu \mathrm{L}$ of sample was injected to GC Shimadzu type 2010 equipped with a capillary column 168 (length $15 \mathrm{~m} \mathrm{ID} 0.25 \mathrm{~mm}$ ) and a flame ionization detector with temperature set to $169370^{\circ} \mathrm{C}$. The carrier gas was helium with a constant delivered flow of $30 \mathrm{~mL} / \mathrm{min}$ and both the injection port and detector temperature was set to $370{ }^{\circ} \mathrm{C}$. 


\subsection{Green metrics calculation}

172 In order to determine how green the AEE process is, the green metrics equations 173 were adopted from previous published report (Sheldon 2018) and used to calculate 174 the environment impact of this study.

$$
E-\text { factor }=\frac{\text { Total mass of waste }}{\text { Mass of oil extracted }}
$$

$$
\text { Process mass intensification }=\frac{\text { Total } \text { mass } \text { in } \text { process }}{\text { Mass of oil extracted }}
$$

$$
\text { Solvent Intensity }=\frac{\text { Mass of solvents }}{\text { Mass of oil extracted }}
$$

$$
\text { Waste water intensity }=\frac{\text { Mass of process water }}{\text { Mass of oil extracted }}
$$

$$
\text { Effective mass yield }=\frac{\text { Mass of oil extracted }}{\text { Mass of hazardous reactants }}
$$

\subsection{Statistical analysis}

182 The significant effect of the ratio of palm kernel to water, $\mathrm{pH}$, temperature, incubation 183 time, and concentration of digestive drug used to the independent parameters such as extraction efficiency, free fatty acid content and lipid composition as MG, DG and TG were statistically analysed using Statistica v13.3 software at significance level set to $\alpha=0.05$. The results are expressed as mean \pm SD. One way analysis of variance (ANOVA) was used to compare the means.

\section{Results and discussion}

The traditional soxhlet method was used to determine the quantity of oil contained in palm kernel. The oil extracted was $39.8 \pm 3.04 \%$ which is in the range of reported oil content in palm kernel (Costa et al. 2019; Tarigan et al. 2017) and the acid value was $1.01 \pm 0.22 \mathrm{mg} / \mathrm{g} \mathrm{KOH}$. The oil dominated by saturated fatty acid was $82.52 \%$ while monounsaturated and polyunsaturated fatty acids were $15.34 \%$ and $2.14 \%$, respectively. Table 1 presents the fatty acid profile of palm kernel oil with lauric acid as the main component dominating more than half. 
Table 1. Fatty acids profile of palm kernel oil

\begin{tabular}{llcc}
\hline \multicolumn{2}{c}{ Fatty Acid } & $\begin{array}{c}\text { Concentration } \\
(\mathrm{g} / 100 \mathrm{~g})\end{array}$ & Percentage \\
\hline $\mathrm{C}_{6: 0} \quad$ Caproic & 0.05 & 0.12 \\
$\mathrm{C}_{8: 0} \quad$ Caprylic & 0.94 & 2.36 \\
$\mathrm{C}_{10: 0} \quad$ Capric & 1.10 & 2.77 \\
$\mathrm{C}_{12: 0} \quad$ Lauric & 20.32 & 51.07 \\
$\mathrm{C}_{14: 0} \quad$ Myristic & 6.54 & 16.43 \\
$\mathrm{C}_{16: 0} \quad$ Palmitic & 3.15 & 7.92 \\
$\mathrm{C}_{18: 0} \quad$ Stearic & 0.71 & 1.78 \\
$\mathrm{C}_{20: 0} \quad$ Arachidic & 0.03 & 0.08 \\
$\mathrm{C}_{18: 1} \quad$ Oleic & 6.11 & 15.34 \\
$\mathrm{C}_{18: 2} \quad$ Linoleic & 0.82 & 2.05 \\
$\mathrm{C}_{20: 1} \quad$ Gondoic & 0.03 & 0.07 \\
Total fatty acids & 39.8 & \\
Saturated & 32.84 & 82.52 \\
Monounsaturated & 6.11 & 15.34 \\
Polyunsaturated & 0.85 & 2.14 \\
\hline
\end{tabular}

203

204 3.1. Effect of ratio palm kernel : water

205 The amount of solvent use to extract oil is important as it affects the oil extracted 206 quantity and the following procedure for oil-solvent separation (Halim et al. 2012). 207 Zakaria and Harvey explained that, based on Fick's law of diffusion, increasing the 208 volume of solvent will increase the quantity of oil extracted (Zakaria and Harvey 209 2012). Therefore, in this study the effect of the ratio of palm kernel to water on the 210 AEE intensified extraction efficiency. The FFA content and lipid profile were 211 investigated at ratio of 1:3 to $1: 7(\mathrm{w} / \mathrm{v})$ with $\mathrm{pH}$ of 9 , concentration of digestive drug of $2127 \% \mathrm{w} / \mathrm{w}$, incubation time of $90 \mathrm{~min}$ and temperature of $45^{\circ} \mathrm{C}$. A ratio below than $1: 3$ is 213 inadequate to immerse the palm kernel seeds. Even though water cannot dissolve 214 lipids, as they have different polarity, the seed to water ratio had a significant effect 215 on all the measured variables. The extraction efficiency ranging from $57.91 \pm 1.60 \%$ 216 to $82.04 \pm 1.60 \%$ with ratio of $1: 5$ was the highest, as shown in Fig. $1 \mathrm{~A}$. This result 217 supports the previously published results which concluded that insufficient water 218 volume prevents the enzyme from penetrating the cell wall while an excess of water 
219 volume decreases the contact of the enzyme and substrate causing low yield (Zhang 220 et al. 2007; Mat Yusoff et al. 2015). The FFA content of the palm oil extracted ranged 221 from $0.39 \pm 0.03 \%$ to $0.66 \pm 0.03 \%$.

222

223 Water had a significant effect on MG, DG and TG content with the yield ranging from $2240.35 \pm 0.29 \%$ to $0.60 \pm 0.62 \%, 1.37 \pm 0.02 \%$ to $2.19 \pm 0.13 \%$ and $19.91 \pm 0.37$ to $22526.16 \pm 0.70 \%$, respectively. As shown in Fig. 2 the highest yield of MG was 226 obtained using ratio of 1:6, while for DG occurred in a ratio of 1:5, and TG had 227 maximum yield when the ratio of 1:4 was applied. The average yield of MG, DG, and $228 \mathrm{TG}$ in this study was $0.47,1.17$, and $22.94 \%$, respectively.

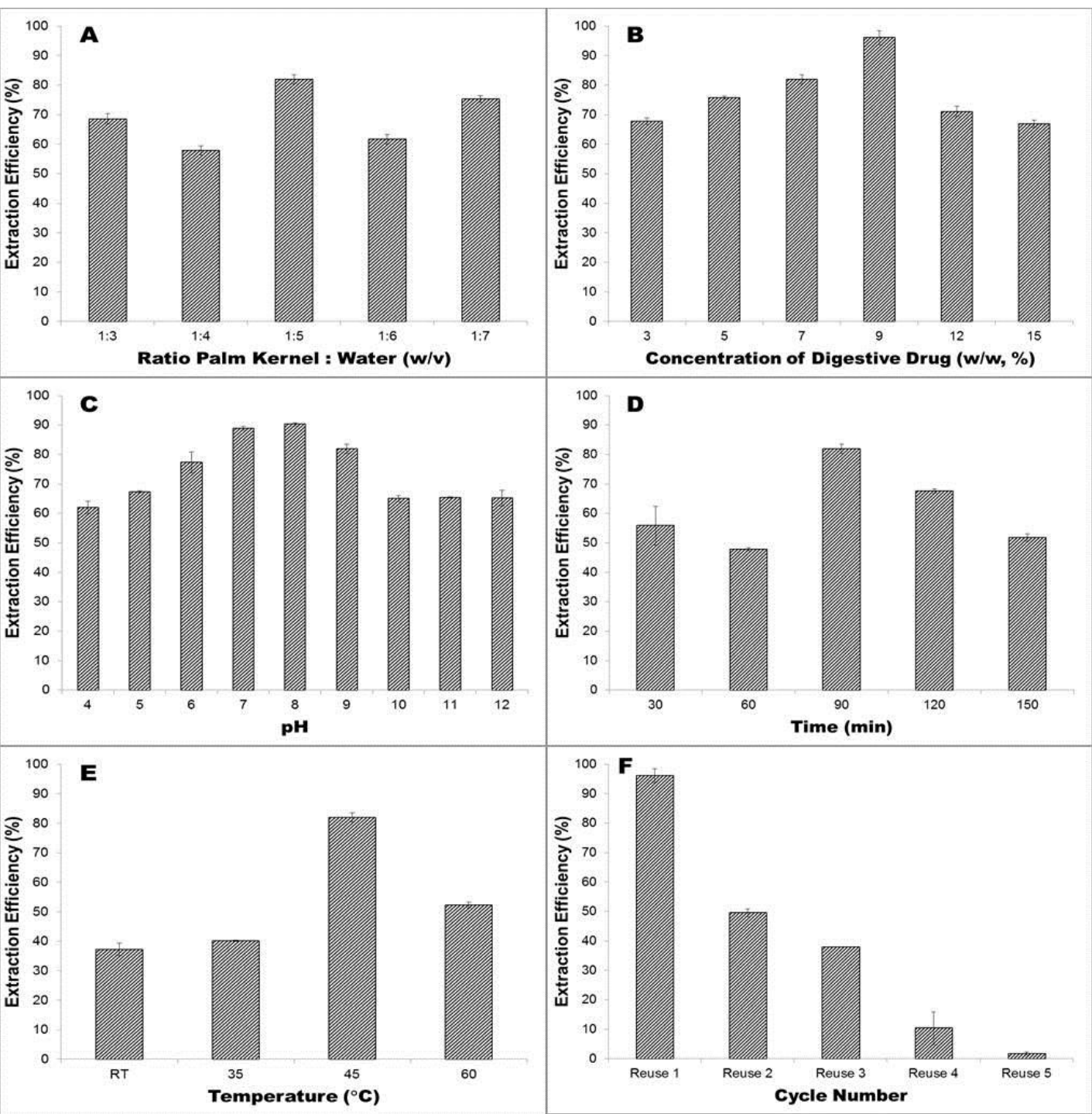

Fig. 1 The effect of $(A)$ ratio palm kernel to water; $(B)$ concentration of digestive 231 drug; $(C) \mathrm{pH}$; $(\mathrm{D})$ incubation time; $(\mathrm{E})$ temperature and $(\mathrm{F})$ reusability of digestive 232 drug on extraction efficiency of AEE intensified. 

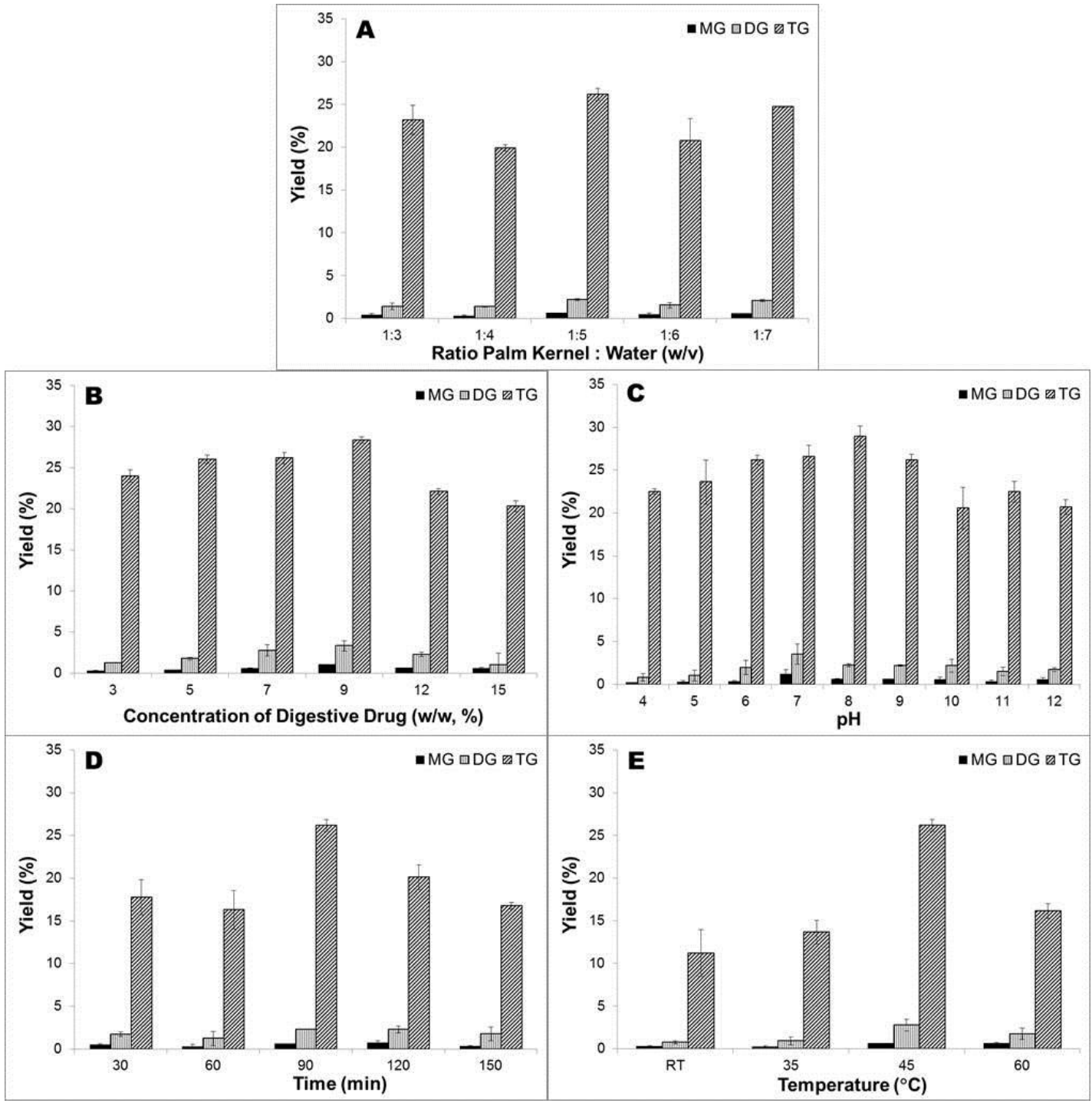

Fig. 2 The effect of $(A)$ ratio palm kernel to water; (B) weight of digestive drug; (C) $235 \mathrm{pH}$; (D) incubation time and (E) temperature on MG, DG and TG yield of $A E E$ 236 intensified.

\subsection{Effect of concentration of digestive drug}

239 Finding a significant concentration of enzyme in AEE is critical as it affects the 240 hydrolysis of cell walls releasing oil to the environment. Hence the effect of the 241 concentration of the digestive drug used in this study was investigated at six different 242 concentration $(3,5,7,9,12$ and $15 \% \mathrm{w} / \mathrm{w})$ in reaction condition: ratio of palm kernel : 243 water of $1: 5, \mathrm{pH}$ of 9 , temperature of $45^{\circ} \mathrm{C}$ and at 90 min incubation time. As 244 observed, the average extraction efficiency of $76.63 \%$ occurred for all the weights of 245 the digestive drug used. The ANOVA test revealed that the concentration of 246 digestive enzyme had significant effect on the extraction efficiency and free fatty acid 
content. The highest extraction efficiency occurring at the weight of $9 \% \mathrm{w} / \mathrm{w}$ was $96.11 \pm 2.31 \%$. Figure $1 \mathrm{~B}$ shows that the pattern of this parameter is in agreement with some published results, which supports the conclusion that the extraction efficiency increased to reach the maximum levels and decreased when increasing the concentration of enzyme used (Zúñiga et al. 2003; Jiang et al. 2010; Mat Yusoff et al. 2015; Mat Yusoff et al. 2016). This was presumably due to the increasing saturation of substrate rendering less contact of enzyme to cell walls (Jiang et al. 2010).

255

The same trend has obtained for the effect of the weight of digestive drug to MG, DG or TG yield (Fig. 2B). The yield of each lipid profile climbed to reach $1.05 \pm 0.04 \%$, $3.34 \pm 0.61 \%$, and $28.37 \pm 0.41 \%$, respectively, and then dropped to $0.30 \pm 0.07 \%$, $1.01 \pm 1.42 \%$ and $20.29 \pm 0.67 \%$, respectively. Therefore, the univariate test identified a significant effect of the concentration of drug used to lipid profile.

\subsection{Effect of $\mathrm{pH}$}

263 The effect of $\mathrm{pH}$ on extraction efficiency, FFA content and lipid profile were 264 determined based on different $\mathrm{pH}$ values from 4 to 12 with an increment of 1 value. There were significant effects for all independent parameters. Furthermore, the Posthoc Tukey test analysis determined that the significance occurring in extraction efficiency was driven by high efficiency of $>70 \%$ at $\mathrm{pH}$ of 6 to 9 , achieving extraction efficiencies of $77.39 \pm 3.55 \%, 88.94 \pm 0.71 \%, 90.23 \pm 0.53 \%$, and $82.04 \pm 1.60 \%$, respectively. In contrast, the significance of FFA content was forced by $\mathrm{pH}$ of 6,10 , and 12 with percentage of $0.76 \pm 0.02 \%, 0.62 \pm 0.07 \%$ and $0.57 \pm 0.01 \%$, respectively.

The average extraction efficiency for this parameter was $73.76 \%$ with the highest occurring at $\mathrm{pH} 8$ (Fig. 1C). The FFA content ranged from $0.26 \pm 0.01 \%$ to $0.76 \pm$ $0.02 \%$ which is lower than the minimum standard allowed for biodiesel production 276 (Britton and Raston 2015). The highest yield of MG was extracted using pH 7 with $2771.19 \pm 0.51 \%$, while $D G$ yielded of $3.53 \pm 1.17 \%$ at the same $\mathrm{pH}$. The maximum yield of TG was obtained using $\mathrm{pH} 8$ with valued at $28.96 \pm 1.16 \%$. 
282 Another important variable that could affect the extracted oil yield is incubation time. 283 Hence five different incubation times were studied starting from $30 \mathrm{~min}$ to $150 \mathrm{~min}$ using the ratio of palm kernel to water of $1: 5,7 \% \mathrm{w} / \mathrm{w}$ of weight of the digestive drug, a temperature of $45^{\circ} \mathrm{C}$ and a pH of 9 . As shown in Figure 1D, incubation time had significant effect against extraction efficiencies and FFA content. The average extraction efficiencies are $61.06 \%$, ranging from $47.86 \pm 0.53 \%$ to $82.04 \pm 1.60 \%$. Prolonged incubation time observed did not increase the yield. This becomes constant indicating that the solubility of oils is saturated or the limitation of active enzymes. Contrary to expectations, this result does not support the previous research. Some studies showed that addition incubation time could increase the oil yield (Jiang et al. 2010; Rui et al. 2009). However, the rate of increase was not economic and the quality of oil also decreased. Furthermore, increasing the incubation time increased the difficulty in oil purification (Liu et al. 2016). A main significant effect was detected for an incubation time of $90 \mathrm{~min}$ that yielded the highest extraction efficiency. In contrast, the significant effect for FFA content was driven by an incubation time of $150 \mathrm{~min}$ that produced the highest percentage $(0.97$ $298 \pm 0.01 \%)$.

299

Incubation time had a significant effect on the MG, DG and TG (Fig. 2D). Extraction 301 of MG, DG, and TG was significantly lower at the incubation time of 60 min achieving 302 yields of $0.28 \pm 0.31 \%, 1.24 \pm 0.82$ and $16.31 \pm 2.26 \%$, respectively. In contrast, highest extractions of $M G$ and $D G$ were obtained at the incubation time of $120 \mathrm{~min}$ 304 giving yields of $0.72 \pm 0.26 \%$ and $2.29 \pm 0.40 \%$, while the maximum yield for $T G$ of $26.16 \pm 0.70 \%$ occurred at incubation time of $90 \mathrm{~min}$.

\subsection{Effect of temperature}

308 Recent evidence suggested that the high hydrolytic activity of enzymes on AEE intensifies the process at a temperature range of $40^{\circ} \mathrm{C}-55^{\circ} \mathrm{C}$ (Mat Yusoff et al. 2015; Rui et al. 2009). However, considering production cost, low 311 incubation temperature is preferable, as maintaining thermal conditions in 312 prolonged reaction time is cost intensive. Therefore, the effect of temperature 313 in this study was investigated ranging from room temperature to $60^{\circ} \mathrm{C}$. 
314 A significant effect was observed in this parameter for extraction efficiency and FFA content. This was mainly driven by high extraction efficiency at a temperature of $45^{\circ} \mathrm{C}$, while FFA content was significantly influenced by high concentration of $0.73 \pm$ $3170.08 \%$ at a temperature of $60^{\circ} \mathrm{C}$. The average extraction efficiency was $51.93 \%$ 318 ranging from $37.19 \pm 2.13 \%$ to $82.04 \pm 1.60 \%$ (Fig. 1E). The FFA content was observed to increase in the increasing incubation temperature. This result supports previous research as mentioned above. Average extraction yield of MG, DG and TG for the effect of temperature was $0.44 \%, 1.55 \%$ and $16.52 \%$, respectively. The highest MG concentration of $0.65 \pm 0.09 \%$ was observed at a temperature of $60^{\circ} \mathrm{C}$, while DG and TG had highest yield at $45^{\circ} \mathrm{C}$ of $2.78 \pm 0.70 \%$ and $26.17 \pm 0.70 \%$, respectively.

\subsection{Reusability of the digestive drug}

327 One factor for reducing production cost in enzymatic method is reusing the enzyme (Santos et al. 2020). To assess the reusability of the enzymes contained in a digestive drug, the incubation was set based on the condition giving the highest oil yield which is ratio palm kernel to water of $1: 5$, weight of digestive drug of $9 \% \mathrm{w} / \mathrm{w}, \mathrm{pH}$ of 9 , incubation time of $90 \mathrm{~min}$ at $45^{\circ} \mathrm{C}$. Figure $1 \mathrm{~F}$ illustrates the extraction efficiency decrease in the second cycle and almost nothing after the fifth cycle. It seems the enzymes lost contact with the cell walls, as the residue from first cycle remains in the environment. Even though the result of this study is similar to previous published results (Nguyen et al. 2020) regarding the decrease of oil yield after a second cycle, the reduced yield in this study after a second cycle is too high, presumably due to the mixture of enzymes used in this study compared to using a single enzyme.

\subsection{Green metrics assessment}

341 Environmental concern has driven the demand to determine how green the chemicals process is (Curzons et al. 2001; Sheldon 2018). The term 'green chemistry' was used to describe the chemical process which generates less waste in the production process and avoids the use of hazardous chemicals.

345 In this study the green chemistry metrics such as environmental factor, 346 process mass intensification, solvent intensity, wastewater intensity and 
347 effective mass yield were calculated following equations $3-7$ mentioned 348 above. Due to insufficient published data for other palm kernel extraction 349 methods such as screw press and supercritical carbon dioxide (SCO) 350 methods, a comparison was made using data from the extraction of linseed oil 351 (Pradhan et al. 2010). Table 2 shows the raw data for the green metrics 352 calculation in this study and in other researcher published results.

353

354 Table 2. The mass reactant used in various oil extraction methods.

\begin{tabular}{|c|c|c|c|c|}
\hline Reactants (g) & Soxhlet & AEE & Screw Expeller & Supercritical $\mathrm{CO}_{2}$ \\
\hline Seed & \multicolumn{2}{|c|}{ Palm kernel $^{*}$} & \multicolumn{2}{|c|}{ Linseed(Pradhan et al. 2010) } \\
\hline Seed weight & 20 & 20 & 20 & 20 \\
\hline Seed residue & 12.04 & 12.35 & 14.9 & 12.94 \\
\hline Hexane & 131 & 0 & 0 & 0 \\
\hline Water & 0 & 100 & 0 & 0 \\
\hline Oil & 7.96 & 7.65 & 5.1 & 7.06 \\
\hline
\end{tabular}

* This study

356 The e-factor which determines the ratio of waste product per oil yield showed 357 that the AEE method has less $22 \%$ of waste product than the soxhlet method. 358 The use of organic solvents in soxhlet extraction is harmful, requires a vast 359 quantity of solvent, and has been identified as energy intensive for evaporation 360 solvents (Halim et al. 2012).

362 Table 3. The green metric of different oil extraction methods.

\begin{tabular}{lcccc}
\hline Green Metrics & Soxhlet & AEE & $\begin{array}{c}\text { Screw } \\
\text { Expeller }\end{array}$ & Supercritical $\mathrm{CO}_{2}$ \\
\hline E-Factor $(\mathrm{g} / \mathrm{g})$ & 17.97 & 14.69 & 2.92 & 1.83 \\
Process mass & 18.97 & 15.69 & 3.92 & 2.83 \\
intensification $(\mathrm{g} / \mathrm{g})$ & & & & \\
Solvent intensity $(\mathrm{g} / \mathrm{g})$ & 16.46 & 0 & 0 & 0 \\
Waste water intensity $(\mathrm{g} / \mathrm{g})$ & 0 & 13.07 & 0 & 0 \\
Effective mass yield $(\%)$ & 6.08 & 0 & 0 & 0 \\
\hline
\end{tabular}

364 It also apparent in Table 3 that the AEE processes performed better in the process of mass intensification, solvent intensity and effective mass yield than 
the soxhlet method. However due to the use of water as a solvent, the AEE method had a higher waste water intensity than the soxhlet method. The screw expeller and SCO methods which have been categorized as green processes (Herrero and Ibáñez 2015; Sheldon 2018) showed better green metrics in all the parameters calculated. This is because no toxic solvents were used and no waste water was produced. In general, the SCO method has better green metrics indicator than other methods.

373

However, related to the direct cost of production such as energy consumption and time consumption, the SCO is the disadvantage method (Nguyen et al. 2020). For example, Pradhan et al. required $180 \mathrm{~min}$ of extraction time to obtain an oil yield of $35.5 \%$ at a temperature of $50^{\circ} \mathrm{C}$ and a pressure of 30 MPa while in only 12 min $25.5 \%$ oil yield was produced using the screw press process. However, the extraction efficiency, calculated based on the soxhletoil yield, of the AEE method is actually better than the other two green processes. The extraction efficiency of $96 \%$ was observed in the AEE process while $65 \%$ and $91 \%$ occurred from screw press and SCO methods, 383 respectively.

\section{Conclusions}

386

The utilization of a commercial digestive drug as enzyme source for the AEE 387 of palm kernel has been developed using various production variables. The extraction efficiency of $96 \%$ with FFA content less than the standard required for vegetable oil and biodiesel raw material was achieved in an incubation condition of $1: 5$ ratio of palm kernel to water, $9 \mathrm{w} / \mathrm{w} \%$ digestive drug, $\mathrm{pH}$ of 9 , and 90 min incubation time at $45^{\circ} \mathrm{C}$. In contrast, the highest $\mathrm{TG}$ yield was observed in a pH of 8 and with $7 \mathrm{w} / \mathrm{w} \%$ digestive drug. There is a significant effect on all parameter studied. Even though the screw press and SCO methods have better green metrics indicators, the extraction efficiency of the AEE process was $31 \%$ and $5 \%$, respectively, better than those processes.

\section{List of abbreviations}

398 AEE Aqueous enzymatic extraction 


$\begin{array}{lll}399 & \text { FFA } & \text { Free fatty acid } \\ 400 & \text { MG } & \text { Monoglyceride } \\ 401 & \text { DG } & \text { Diglyceride } \\ 402 & \text { TG } & \text { Triglyceride } \\ 403 & \text { GC } & \text { Gas chromatography } \\ 404 & \mathrm{NaOH} & \text { Sodium hydroxide } \\ 405 & \mathrm{HCl} & \text { Hydrochloride acid } \\ 406 & \mathrm{KOH} & \text { Potassium hydroxide } \\ 407 & \text { ANOVA } & \text { Analysis of variance } \\ 408 & \text { SCO } & \text { Supercritical carbon dioxide } \\ 409 & & \end{array}$

\section{Declarations}

411 - Ethics approval and consent to participate: Not applicable

412 - Consent for publication: Not applicable

413 - Availability of data and materials: All data generated or analysed during this study

414 are included in this published article and its supplementary information files.

415 - Competing interests: The authors declare that they have no competing interests.

416 - Funding: Not available

417 - Authors contributions:

418 FS conducting the research work and writing the manuscript assisted by MR, 419 FCU and TAH, M assisted in data analysis, JAK and JBT assisted in results and 420 discussion section, SC supported in data analysis and draft revision, and EKT 421 assisted in finalisation and submission manuscript.

- Acknowledgements: The authors would like to acknowledge Universitas 423 Sumatera Utara for the research facilities. The authors also acknowledge Dr. Maria Flutsch for editing the manuscript.

\section{References}

Al-Hamamre Z, Foerster S, Hartmann F, Kröger M, Kaltschmitt M (2012) Oil extracted from spent coffee grounds as a renewable source for fatty acid methyl ester manufacturing. Fuel 96:70-76. doi:https://doi.org/10.1016/j.fuel.2012.01.023

Britton J, Raston CL (2015) Rapid high conversion of high free fatty acid feedstock into biodiesel using continuous flow vortex fluidics. RSC Advances 5 (3):22762280. doi:10.1039/C4RA14909B 
Castejón N, Luna P, Señoráns FJ (2018) Alternative oil extraction methods from Echium plantagineum L. seeds using advanced techniques and green solvents. Food Chemistry

244:75-82. doi:https://doi.org/10.1016/i.foodchem.2017.10.014

Castro-Puyana M, Marina ML, Plaza M (2017) Water as green extraction solvent: Principles and reasons for its use. Current Opinion in Green and Sustainable Chemistry 5:31-36. doi:https://doi.org/10.1016/i.cogsc.2017.03.009

Cheng M-H, Rosentrater KA (2017) Economic feasibility analysis of soybean oil production by hexane extraction. Industrial Crops and Products 108:775-785. doi:https://doi.org/10.1016/j.indcrop.2017.07.036

Costa WAd, Bezerra FWF, Oliveira MSd, Andrade EHdA, Santos APMd, Cunha VMB, Santos DCSd, Banna DADdS, Teixeira E, Carvalho Junior RNd (2019) Supercritical $\mathrm{CO} 2$ extraction and transesterification of the residual oil from industrial palm kernel cake with supercritical methanol. The Journal of Supercritical Fluids 147:179-187. doi:https://doi.org/10.1016/i.supflu.2018.10.012

Curzons AD, Constable DJC, Mortimer DN, Cunningham VL (2001) So you think your process is green, how do you know?-Using principles of sustainability to determine what is green-a corporate perspective. Green Chemistry 3 (1):16. doi:10.1039/B007871।

Dal Prá V, Soares JF, Monego DL, Vendruscolo RG, Guimarães Freire DM, Alexandri M, Koutinas A, Wagner R, Mazutti MA, Da Rosa MB (2018) Comparison of Different Compressed Fluids for Residual Oil Extraction from Palm Kernel Cake. Waste and Biomass Valorization 9 (2):265-271. doi:10.1007/s12649-016-9778-8

de Jesus SS, Ferreira GF, Moreira LS, Wolf Maciel MR, Maciel Filho R (2019) Comparison of several methods for effective lipid extraction from wet microalgae using green solvents. Renewable Energy 143:130-141. doi:https://doi.org/10.1016/j.renene.2019.04.168

de Oliveira RC, de Barros STD, Gimenes ML (2013) The extraction of passion fruit oil with green solvents. Journal of Food Engineering 117 (4):458-463. doi:https://doi.org/10.1016/i.jfoodeng.2012.12.004

Drugbank (2005) Pancrelipase. https://www.drugbank.ca/drugs/DB00085. Accessed 12 September 20202020

Halim R, Danquah MK, Webley PA (2012) Extraction of oil from microalgae for biodiesel production: A review. Biotechnology Advances 30 (3):709-732. doi:http://dx.doi.org/10.1016/j.biotechadv.2012.01.001

He Y, Zhang B, Guo S, Guo Z, Chen B, Wang M (2020) Sustainable biodiesel production from the green microalgae Nannochloropsis: Novel integrated processes from cultivation to enzyme-assisted extraction and ethanolysis of lipids. Energy Conversion and Management 209:112618. doi:https://doi.org/10.1016/i.enconman.2020.112618

Herrero M, Ibáñez E (2015) Green processes and sustainability: An overview on the extraction of high added-value products from seaweeds and microalgae. The Journal of Supercritical Fluids 96:211-216. doi:10.1016/j.supflu.2014.09.006

Jiang L, Hua D, Wang Z, Xu S (2010) Aqueous enzymatic extraction of peanut oil and protein hydrolysates. Food and Bioproducts Processing 88 (2):233-238. doi:https://doi.org/10.1016/j.fbp.2009.08.002

Jung S, Mahfuz AA (2009) Low temperature dry extrusion and high-pressure processing prior to enzyme-assisted aqueous extraction of full fat soybean 
flakes.

Food

Chemistry

114

(3):947-954.

485

486

487

488

489

490

491

492

493

494

495

496

497

498

499

500

501

502

503

504

505

506

507

508

509

510

511

512

513

514

515

516

517

518

519

520

521

522

523

524

525

526

527

528

529

530

531

532

533

doi:https://doi.org/10.1016/i.foodchem.2008.10.044

Kumar SPJ, Prasad SR, Banerjee R, Agarwal DK, Kulkarni KS, Ramesh KV (2017) Green solvents and technologies for oil extraction from oilseeds. Chemistry Central Journal 11 (1):9. doi:10.1186/s13065-017-0238-8

Lamsal BP, Murphy PA, Johnson LA (2006) Flaking and extrusion as mechanical treatments for enzyme-assisted aqueous extraction of oil from soybeans. J Amer Oil Chem Soc 83 (11):973-979. doi:10.1007/s11746-006-5055-5

Latif S, Anwar F (2009) Effect of Aqueous Enzymatic Processes on Sunflower Oil Quality. J Amer Oil Chem Soc 86 (4):393-400. doi:10.1007/s11746-009-13578

Latif S, Anwar F (2011) Aqueous enzymatic sesame oil and protein extraction. Food Chemistry 125

(2):679-684. doi:https://doi.org/10.1016/j.foodchem.2010.09.064

Lebenthal E, Rolston DDK, Holsclaw DSJ (1994) Enzyme Therapy for Pancreatic Insufficiency: Present Status and Future Needs. Pancreas 9 (1):1-12

Li Y, Jiang L, Sui X, Wang S (2011) Optimization of the aqueous enzymatic extraction of pine kernel oil by response surface methodology. Procedia Engineering 15:4641-4652. doi:https://doi.org/10.1016/j.proeng.2011.08.872

Liu C, Hao L, Chen F, Yang C (2020) Study on Extraction of Peanut Protein and Oil Bodies by Aqueous Enzymatic Extraction and Characterization of Protein. Journal of Chemistry 2020:5148967. doi:10.1155/2020/5148967

Liu J-j, Gasmalla MAA, Li P, Yang R (2016) Enzyme-assisted extraction processing from oilseeds: Principle, processing and application. Innovative Food Science \& Emerging Technologies 35:184-193. doi:https://doi.org/10.1016/j.ifset.2016.05.002

Long J-j, Fu Y-j, Zu Y-g, Li J, Wang W, Gu C-b, Luo M (2011) Ultrasound-assisted extraction of flaxseed oil using immobilized enzymes. Bioresource Technology 102 (21):9991-9996. doi:https://doi.org/10.1016/j.biortech.2011.07.104

Mat Yusoff M, Gordon MH, Ezeh O, Niranjan K (2016) Aqueous enzymatic extraction of Moringa oleifera oil. Food Chemistry 211:400-408. doi:https://doi.org/10.1016/j.foodchem.2016.05.050

Mat Yusoff M, Gordon MH, Niranjan K (2015) Aqueous enzyme assisted oil extraction from oilseeds and emulsion de-emulsifying methods: A review. Trends in Food Science \& Technology 41 (1):60-82. doi:https://doi.org/10.1016/j.tifs.2014.09.003

MIMS (2020) Vitazym. https://www.mims.com/indonesia/drug/info/vitazym. Accessed 22 September 2020

Mouahid A, Bouanga H, Crampon C, Badens E (2018) Supercritical CO2 extraction of oil from Jatropha curcas: An experimental and modelling study. The Journal of Supercritical Fluids 141:2-11. doi:https://doi.org/10.1016/j.supflu.2017.11.014

Nguyen HC, Vuong DP, Nguyen NTT, Nguyen NP, Su C-H, Wang F-M, Juan H-Y (2020) Aqueous enzymatic extraction of polyunsaturated fatty acid-rich sacha inchi (Plukenetia volubilis L.) seed oil: An eco-friendly approach. LWT 133:109992. doi:https://doi.org/10.1016/j.Iwt.2020.109992

OECD, Food, Nations AOotU (2020) OECD-FAO Agricultural Outlook 2020-2029. doi:doi:https://doi.org/10.1787/1112c23b-en

Potrich E, Miyoshi SC, Machado PFS, Furlan FF, Ribeiro MPA, Tardioli PW, Giordano RLC, Cruz AJG, Giordano RC (2020) Replacing hexane by ethanol 
for soybean oil extraction: Modeling, simulation, and techno-economicenvironmental analysis. Journal of Cleaner Production 244:118660. doi:https://doi.org/10.1016/j.jclepro.2019.118660

Pradhan RC, Meda V, Rout PK, Naik S, Dalai AK (2010) Supercritical CO2 extraction of fatty oil from flaxseed and comparison with screw press expression and solvent extraction processes. Journal of Food Engineering 98 (4):393-397. doi:https://doi.org/10.1016/i.jfoodeng.2009.11.021

Rui H, Zhang L, Li Z, Pan Y (2009) Extraction and characteristics of seed kernel oil from white pitaya. Journal of Food Engineering 93 (4):482-486. doi:https://doi.org/10.1016/i.jfoodeng.2009.02.016

Santos S, Puna J, Gomes J (2020) A Review on Bio-Based Catalysts (Immobilized Enzymes) Used for Biodiesel Production. Energies 13 (11):3013

Sheldon RA (2018) Metrics of Green Chemistry and Sustainability: Past, Present, and Future. ACS Sustainable Chemistry \& Engineering 6 (1):32-48. doi:10.1021/acssuschemeng.7b03505

Sitepu EK, Heimann K, Raston CL, Zhang W (2020) Critical evaluation of process parameters for direct biodiesel production from diverse feedstock. Renewable and Sustainable Energy Reviews 123:109762. doi:https://doi.org/10.1016/i.rser.2020.109762

Tarigan JB, Ginting M, Mubarokah SN, Sebayang F, Karo-karo J, Nguyen TT, Ginting J, Sitepu EK (2019) Direct biodiesel production from wet spent coffee grounds. RSC Advances 9 (60):35109-35116. doi:10.1039/C9RA08038D

Tarigan JB, Prakoso HT, Siahaan D, Kaban J (2017) Rapid Biodiesel Production From Palm Kernel Through In Situ Transesterification Reaction Using $\mathrm{CaO}$ as Catalyst. International Journal of Applied Chemistry 13 (3):631-646

Teixeira CB, Macedo GA, Macedo JA, da Silva LHM, Rodrigues AMdC (2013) Simultaneous extraction of oil and antioxidant compounds from oil palm fruit (Elaeis guineensis) by an aqueous enzymatic process. Bioresource Technology 129:575-581. doi:https://doi.org/10.1016/..biortech.2012.11.057

Toda TA, Sawada MM, Rodrigues CEC (2016) Kinetics of soybean oil extraction using ethanol as solvent: Experimental data and modeling. Food and Bioproducts Processing 98:1-10. doi:https://doi.org/10.1016/j.fbp.2015.12.003

Wan L-S, Ke B-B, Xu Z-K (2008) Electrospun nanofibrous membranes filled with carbon nanotubes for redox enzyme immobilization. Enzyme and Microbial Technology 42

(4):332-339. doi:https://doi.org/10.1016/i.enzmictec.2007.10.014

Wenwei C, Guangrong H, Zhenbao J, Yao H (2019) Optimization of aqueous enzymatic extraction of oil from shrimp processing by-products using response surface methodology. Food Science and Technology 39:231-236

Womeni HM, Ndjouenkeu R, Kapseu C, Mbiapo FT, Parmentier M, Fanni J (2008) Aqueous enzymatic oil extraction from Irvingia gabonensis seed kernels. European Journal of Lipid Science and Technology 110 (3):232-238. doi:10.1002/ejlt.200700172

Yao Y, Liu C, Xiong W, Liang Q, Xuan P, Zeng X, Zeng S, Zhou Q, Huang F (2020) Silicon dioxide as an efficient adsorbent in the degumming of rapeseed oil. Journal of Cleaner Production 268:122344. doi:https://doi.org/10.1016/j.jclepro.2020.122344

Zakaria R, Harvey AP (2012) Direct production of biodiesel from rapeseed by reactive extraction/in situ transesterification. Fuel Processing Technology 102:53-60. doi:http://dx.doi.org/10.1016/j.fuproc.2012.04.026 
Zhang SB, Wang Z, Xu SY (2007) Optimization of the Aqueous Enzymatic Extraction of Rapeseed Oil and Protein Hydrolysates. J Amer Oil Chem Soc 84 (1):97105. doi:10.1007/s11746-006-1004-6

Zhao Q, Li P, Wang M, Zhang W, Zhao W, Yang R (2020) Fate of phospholipids during aqueous extraction processing of peanut and effect of demulsification treatments on oil-phosphorus-content. Food Chemistry 331:127367. doi:https://doi.org/10.1016/j.foodchem.2020.127367

Zúñiga ME, Soto C, Mora A, Chamy R, Lema JM (2003) Enzymic pre-treatment of Guevina avellana mol oil extraction by pressing. Process Biochemistry 39 (1):51-57. doi:https://doi.org/10.1016/S0032-9592(02)00286-8 
Figures

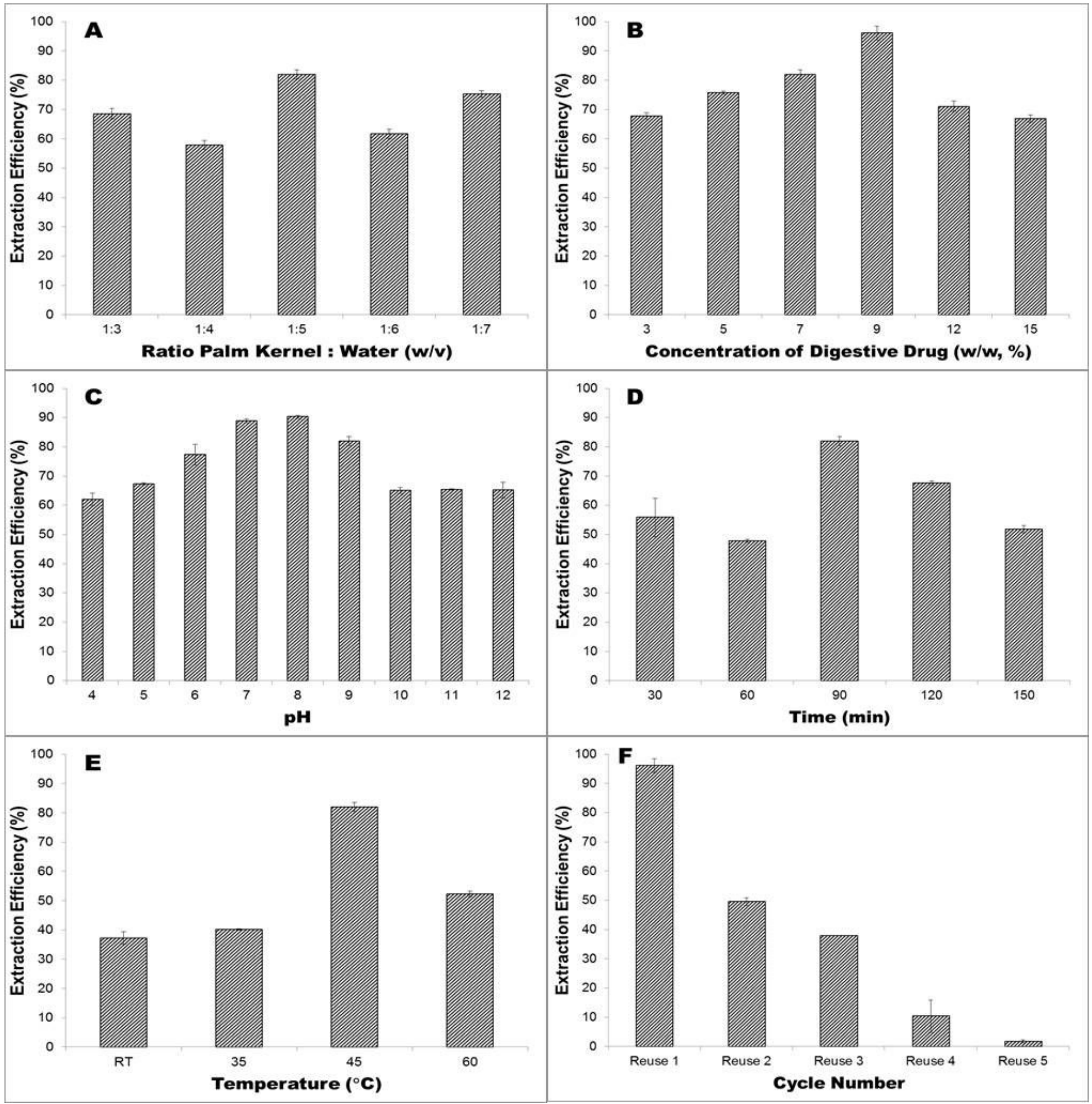

Figure 1

The effect of $(A)$ ratio palm kernel to water; $(B)$ concentration of digestive drug; $(C) p H ;(D)$ incubation time; $(E)$ temperature and $(F)$ reusability of digestive drug on extraction efficiency of AEE intensified. 

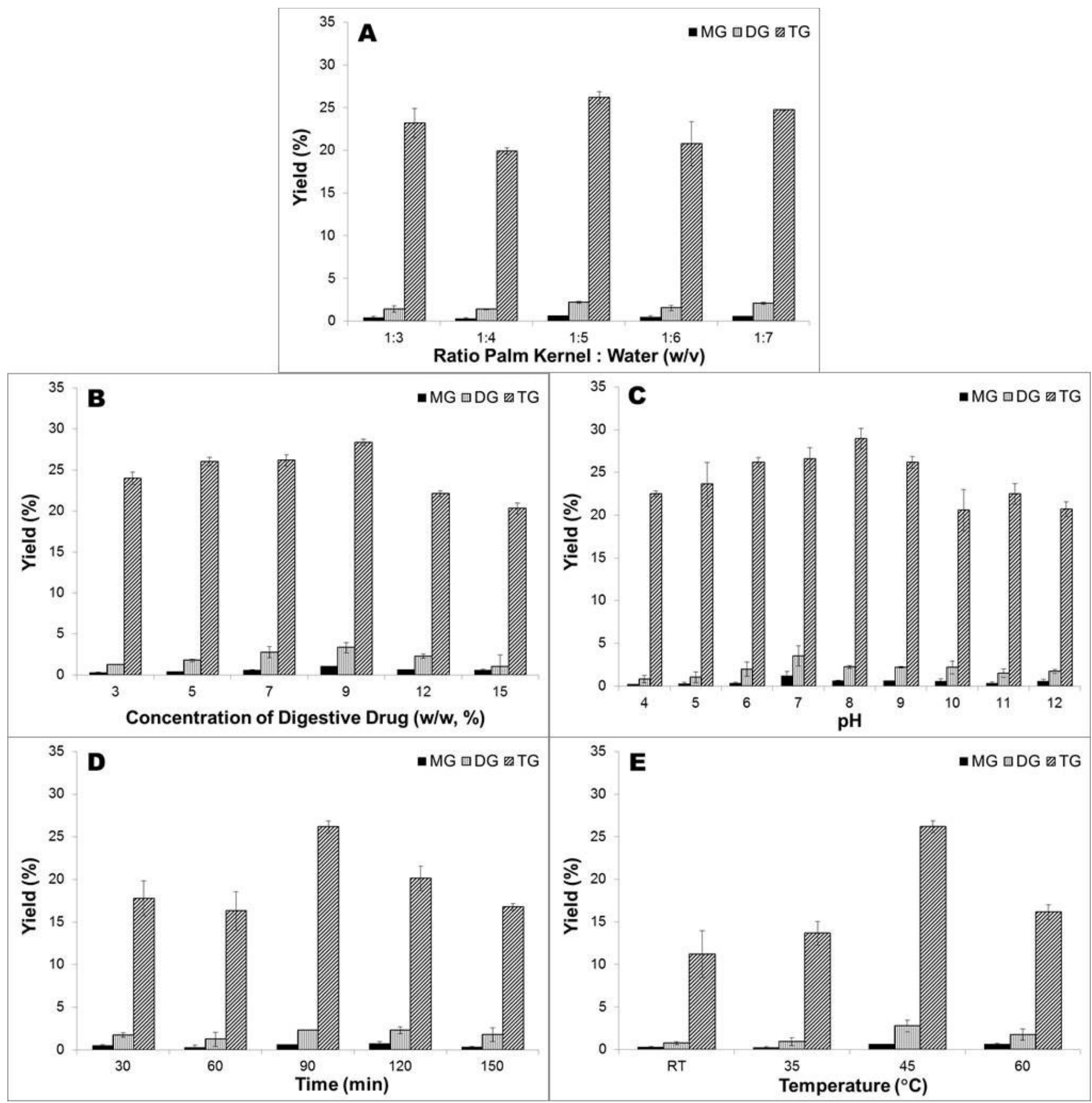

Figure 2

The effect of $(A)$ ratio palm kernel to water; $(B)$ weight of digestive drug; $(\mathrm{C}) \mathrm{pH}$; $(\mathrm{D})$ incubation time and (E) temperature on $M G, D G$ and $T G$ yield of $A E E$ intensified.

\section{Supplementary Files}

This is a list of supplementary files associated with this preprint. Click to download. 
- GraphicalAbstract.tif

- Supplementarylnformation.docx 